Rafał Mańko

Uniwersytet Amsterdamski e-mail: r.t.manko@uva.nl telefon: +3120525 7347

DOI: $10.15290 /$ mhi.2017.16.02.05

\title{
Idee polityczne i prawne a kultura unijnego prawa prywatnego - przyczynek do dalszych badań*
}

\begin{abstract}
SUMMARY
Politico-juridical ideas and the culture of Union private law: notes towards further research

The present paper analyses the ideological foundations of the culture of European private law. The paper groups the possible politico-juridical ideas in opposing pairs, noting the domination of neofunctionalism over a systematic approach to law; pragmatism over formalism, instrumentalism over autonomy and technocratism over democratism, as well as liberalism over social justice, consumerism over citizenship and intergration
\end{abstract} over national sovereignty.

Key words: private law, ideology, legal culture

Słowa kluczowe: prawo prywatne, ideologia, kultura prawna

\section{Uwagi wprowadzające}

Piśmiennictwo dotyczące prawa prywatnego Unii Europejskiego (unijnego prawa prywatnego) skupia się przede wszystkim na jego dogmatyce. Podejście takie jest zrozumiałe zważywszy, że unijne dyrektywy i rozporządzenia w dziedzinie prawa prywatnego należą do systemu prawa pozytywnego UE, a więc ich moc obowiązująca obejmuje także Polskę. Znacznie mniej jest natomiast literatury analizującej kulturę prawną wyrosłą nad podglebiu unijnego prawa prywatnego (kulturę unijnego prawa prywatnego), a w szczególności jej zaplecze ideowe. Niniejszy artykuł stawia sobie za cel podjęcie rozważań dotyczących właśnie wpływu idei politycznych i prawnych na kulturę unijnego prawa prywatnego.

* Artykuł niniejszy powstał w ramach projektu badawczego Narodowego Centrum Nauki nr UMO-2016/21/B/HS5/03221. 
Zamierzeniem artykułu jest próba zrekonstruowania roboczego i niewyczerpującego katalogu idei politycznych i prawnych, których mniej lub bardziej wyraźną realizację możemy odnaleźć w unijnej kulturze prawa prywatnego. Dla celów analizy idee zostały ułożone w pary przeciwieństw, na podobieństwo alleli w genetyce - dominujących i recesywnych. Jak wiadomo, allel dominujący $\mathrm{w}$ zetknięciu $\mathrm{z}$ allelem recesywnym determinuje fenotyp, natomiast nie wyklucza to, że $w$ kolejnych organizmach allel recesywny wpłynie jednak na kształt fenotypu, tj. „ujrzy światło dziennie”. Metaforycznie ${ }^{1}$ to samo powiedzieć można o ideach - idee dominujące zazwyczaj determinują kształt określonych zjawisk danej kultury prawnej, jednakże ich przeciwieństwa - idee recesywne, również niekiedy dochodzą do głosu. Wpływ określonych idei politycznych i prawnych na daną kulturę prawną nie jest bowiem automatyczny i prosty, lecz ma charakter wieloczynnikowy i złożony, czego ilustracją będą poniższe rozważania o kulturze unijnego prawa prywatnego.

Ponadto, pary przeciwstawnych idei-alleli zostaną podzielone na dwie grupy - idee "formalne” i idee „materialne”. Idee formalne dotyczyć będą sposobu uporządkowania materiału prawnego, jego systematyki, terminologii, wysłowienia, metod rozumowania prawniczego, słowem tego wszystkiego, co stanowi o zewnętrznej postaci prawa. Idee materialne dotyczyć będą natomiast konkretnej treści rozstrzygnięć, czy to zawartych $\mathrm{w}$ tekstach prawa pozytywnego, czy w prawie operatywnym.

Przed przejściem do właściwych rozważań konieczne jest poczynienie wielu dalszych założeń terminologicznych i pojęciowych. Po pierwsze, pojęcie „kultury prawnej” będzie tu rozumiane jako całokształt przyjętych przez daną wspólnotę prawniczą reguł wyznaczających odpowiedni (wzorcowy, społecznie pożądany) sposób uprawiania praktyk prawniczych przez członków tej wspólnoty (a zatem praktyk: stanowienia, wykładni i stosowania prawa), następnie ramy instytucjonalne, $\mathrm{w}$ jakich praktyki te są uprawiane (struktura sądownictwa, akademii prawniczej, legislatywy), świadomość aktorów prawniczych praktyk (włącznie z ideologią i aksjologią), jak też wreszcie wszelkie wytwory materialne prawniczych praktyk (w szczególności orzecznictwo, piśmiennictwo, przepisy prawa) ${ }^{2}$. Tak rozumiana kultura prawna obejmuje to,

1 G. Lacoff, M. Johnson, Metaphors We Live By, Chicago 2003; zob. także Z. Kövecses, Metaphor: A Practical Introduction, Oxford 2010. W polu prawnym zob. np. S. Larsson, Metaphors and Norms: Understanding Copyright in a Digital Society, Lund 2011.

2 Por. M. Hesselink, The New European Legal Culture, Deventer 2002, s. 9; R. Mańko, Culture of Private Law in Central Europe After Enlargment: A Polish Perspective, "European Law Journal" (dalej: ELJ) 2005, nr 11, z. 5, s. 527; idem, The Unification of Private Law in Europe from the Perspective of Polish Legal Culture, "Yearbook of Polish European Studies" 2007-2008, nr 11, s. 112-113; idem, Relikty w kulturze prawnej. Uwagi metodologiczne na tle pozostałości epoki socjalizmu realnego w polskim prawie prywatnym, „Przegląd Prawa i Administracji” (dalej: PPiA) 2015, t. 102, s. 201, przyp. 3. Zob. także Å.B. Grødeland, W.L. Miller, European Legal Cultures in Transition, Cambridge 2015, s. 2-5. O pojęciu „kultury” w kontekście procesu integracji europejskiej zob. W. Jedlecka, Legitymizacja prawa Unii Europejskiej. Legitymizacja demokratyczna czy cywilizacyjna?, Łódź 2014, s. 165-200. 
co niemieccy komparatyści K. Zweigert i H. Kötz określali mianem „stylu” prawnego ${ }^{3}$, a zatem w szczególności systematykę prawa, system uznanych źródeł prawa, stylizację aktów prawnych, dominujące formy argumentacji prawniczej oraz styl orzeczeń sądowych. Poza zakresem tak rozumianej kultury prawnej pozostawiam natomiast kulturę prawną społeczeństwa (świadomość prawną społeczeństwa, dominujące poglądy na prawo).

Delimitacja „unijnej kultury prawa prywatnego" wymaga odwołania się do pojęcia "unijnego prawa prywatnego", stanowiącego podglebie dla omawianej kultury prawnej ${ }^{4}$. Przez unijne prawo prywatne rozumiany będzie ogół przepisów prawa pozytywnego Unii Europejskiej ${ }^{5}$ regulujących zagadnienia $\mathrm{z}$ zakresu prawa prywatnego, tj. materialnego (cywilne, handlowe), procesowego oraz kolizyjnego. Z kolei pojęcie "tekstów unijnej kultury prawa prywatnego" obejmować będzie wszelkie teksty wytwarzane w ramach praktyk kultury prawnej, a zatem nie tylko wskazane wyżej teksty przepisów prawa obowiązującego, ale także akty stosowania prawa, projekty tworzone przez rozmaite grupy badawcze (których rola w kulturze unijnego prawa prywatnego jest nie do przecenienia), a także poglądy wyrażane przez doktrynę unijnego prawa prywatnego.

\section{Idee formalne}

\section{1. (Neo)funkcjonalizm versus systemowość}

Spośród idei, które zdeterminowały zakres, kształt i systematykę unijnego prawa prywatnego na czoło wysuwa się idea neofunkcjonalizmu, która legła zresztą u podstaw całego procesu integracji europejskiej ${ }^{6}$. Ideę neofunkcjonalizmu można w uproszczeniu sprowadzić do poglądu, wedle którego państwa, wchodząc w układy integracji regionalnej, przestają być w pełni suwerenne, lecz przekazują swe kompetencje w precyzyjnie określonych dziedzinach podmiotowi lub podmiotom integracji ponadnarodowej. Tym, co odróżnia tak ro-

3 Zob. K. Zweigert \& H. Kötz, Introduction to Comparative Law, wyd. 3, Oxford 1998, s. 68-72. Por. R. Mańko, Survival of the Socialist Legal Tradition? A Polish Perspective, "Comparative Law Review" 2013, R. IV, z. 2, s. 3-4.

4 Poza zakresem rozważań niniejszego artykułu pozostawione zostaje natomiast zagadnienie ewentualnego istnienia wspólnoty epistemicznej europejskich cywilistów („,wspólnoty eurocywilistycznej"). Pominięcie tego aspektu, istotnego z perspektywy socjologii prawa, wynika z przyjętego tu ujęcia badawczego, które skupia się nie na aktorach kultury prawnej (np. profesorach, urzędnikach, sędziach, adwokatach), ale na realizacji określonych idei, przyjętych za istniejące apriorycznie.

5 Jak wskazuje M. Zirk-Sadowski, wyodrębnienie się prawa wspólnotowego (obecnie: unijnego) jako porządku prawnego nastąpiło od $1960 \mathrm{r}$. M. Zirk-Sadowski, Prawo a uczestniczenie w kulturze, Łódź 1998, s. 94.

6 M. Bartl, Internal Market Rationality, Private Law and the Direction of the Union: Resuscitating the Market as the Object of the Political, ELJ 2015, R. XXI, z. 5, s. 575. 
zumiany neofunkcjonalizm od federalizmu jest założenie, że na organizację integracyjną przekazywane są jedynie wybrane aspekty (funkcje) władzy publicznej. W odróżnieniu jednak od klasycznego funkcjonalizmu, neofunkcjonalizm podkreśla dynamikę integracji, która jest procesem kroczącym (rozszerzającym się), co nazywane jest „efektem rozlania” (spill-over efect) ${ }^{7}$.

Jak zauważa M. Zając-Fras, neofunkcjonalizm „stanowi najbardziej spójną, ścisłą i metodologicznie poprawną teorię integracji europejskiej"8. W istocie, można doszukiwać się wpływów idei neofunkcjonalizmu (czy też wcześniejszej jego odmiany, zwanej funkcjonalizmem ${ }^{9}$ ) na Deklarację Schumana, która legła u podstaw Europejskiej Wspólnoty Węgla i Stali (EWWiS), poprzedniczki Unii Europejskiej. W swej deklaracji Schuman wskazał, że „Europa nie powstanie ani za jednym razem, ani jako całościowa konstrukcja; będzie powstawała przez realizację konkretnych zadań, tworząc najpierw rzeczywistą solidarność"10. Jak wskazuje M.M. Kenig-Witkowska, EWWIS „może być (...) uważana za laboratoryjny przykład integracji funkcjonalnej, ze wspólnymi instytucjami posiadającymi tylko takie uprawnienia, jakie konieczne są do wywiązywania się z celów określonych w traktacie założycielskim"11.

W projekt europejski, a zatem $\mathrm{w}$ europejską kulturę polityczną, wpisano zatem na samym wstępie założoną fragmentatyczność (wybiórczość), a zatem wyspecjalizowanie się Wspólnot mniej lub bardziej precyzyjnie określonych dziedzinach. Początkowo była to integracja rynków węgla i stali (EWWiS) oraz współpraca w dziedzinie energii atomowej (Euratom). Później - integracja gospodarcza tout court, poczynając od zniesienia barier celnych. Stopniowo, zgodnie ze wspomnianą wyżej teorią rozlania, do zakresu kompetencji Wspólnot dołączano kolejne elementy, takie jak budowa wspólnego rynku (ogłoszona w Jednolitym Akcie Europejskim z 1987 r.), tworzenie przestrzeni bez granic wewnętrznych (układy schengeńskie, później włączone do Traktatów), czy wreszcie budowa „Przestrzeni wolności, bezpieczeństwa i sprawiedliwości", ogłoszona traktatem amsterdamskim. Ideę neofunkcjonalizmu można więc sprowadzić do „metody małych kroków” - obejmowania procesem integracji wybranych, wyspecjalizowanych obszarów, które stopniowo się rozszerzają, a jednocześnie dodawane są do nich obszary nowe, które również ulegają stopniowemu rozszerzaniu.

7 L. McGowan, Theorising European Integration: revisiting neofunctionalism and testing its suitability for explaining the development of EC competition policy?, "European Integration Online Papers" 2007, R. XI, z. 3, http:// eiop.or.at/eiop/pdf/2007-003.pdf (19.10.2015); M. Zając-Frąs, Teorie i modele integracji europejskiej, „Zeszyty Naukowe Uniwersytetu Ekonomicznego w Krakowie” 2011, nr 852, s. $12-14$.

Ibidem, s. 6-7.

10 Por. J. Helios, Prawo prywatne Unii Europejskiej ze stanowiska teorii prawa, Łódź 2014, s. 94-95.

11 M.M. Kenig-Witkowska, [w:] Prawo instytucjonalne Unii Europejskiej, red. eadem, wyd. 6, Warszawa 2015, s. 16. 
Na kulturę unijnego prawa prywatnego neofunkcjonalizm przekłada się w wielu wymiarach. Po pierwsze, bezpośrednio determinuje zakres unijnego prawa prywatnego, $\mathrm{w}$ oderwaniu od historycznie ukształtowanego zakresu prawa prywatnego w kulturach prawnych państwach członkowskich ${ }^{12}$. Determinacja ta odbywa się przez traktatowe umocowania do stanowienia norm prywatnoprawnych przez ustawodawcę unijnego ${ }^{13}$. Początkowo Traktat Rzymski w ogóle takiego umocowania nie przewidywał. W okresie tym normy z zakresu prawa prywatnego tworzono opierając się na kompetencji do harmonizacji na rynku wewnętrznym (początkowo art. 100 Traktatu EWG, później także art. 100 a tego Traktatu). Ponadto uciekano się do klauzuli salwatoryjnej (obecny art. 352 TFUE). Dopiero w wyniku zmian dokonanych w Traktacie z Maastricht, a następnie w Traktacie Amsterdamskim ustawodawca unijny zyskał explicite kompetencje do stanowienia norm prawa prywatnego - przy czym chodziło o prawo procesowe $\mathrm{z}$ elementem transgranicznym oraz prawo prywatne międzynarodowe ${ }^{14}$. Aktualnie, po Traktacie Lizbońskim, ustawodawca unijny dysponuje ponadto kompetencją do tworzenia unijnych praw własności intelektualnej (art. 118 TFUE), do regulowania prawa spółek oraz ograniczone kompetencje do regulowania wybranych aspektów prawa pracy. Państwa członkowskie wciąż nie przyznały Unii kompetencji w dziedzinie prawa prywatnego materialnego ${ }^{15}$. Tym niemniej, ustawodawca unijny wykorzystuje w tym względzie normę art. 114 TFUE zezwalającą Unii na harmonizację przepisów krajowych w celu zapewnienia prawidłowego funkcjonowania wspólnego rynku.

$\mathrm{W}$ praktyce więc ustawodawca unijny stanowi normy z dziedziny prawa prywatnego materialnego na podstawie kompetencji do harmonizacji prawa dotyczącego rynku wewnętrznego, a z dziedziny prawa procesowego i koli-

12 Por. J. Helios, op. cit., s. 102-103.

13 Kompleksową analizę umocowań traktatowych w dziedzinie prawa prywatnego zawierają prace: A. Całus, Umocowanie do zbliżania prawa prywatnego państw członkowskich w prawie Unii Europejskiej, [w:] Europeizacja prawa prywatnego, red. M. Pazdan i in., Warszawa 2008; B. Ziemblicki, Zbliżanie ustawodawstw państw członkowskich Unii Europejskiej w zakresie prawa prywatnego, „Folia Iuridica Wratislaviensis" 2012, R. I, z. 1; R. Mańko, Kompetencje Unii Europejskiej w dziedzinie prawa prywatnego w ujęciu systemowym, "Kwartalnik Prawa Prywatnego" (dalej: KPP) 2016, R. XXV, z. 1.

14 Zob. w szczególności: K. Lubińska, Traktat Lizboński a wspótpraca sądowa w sprawach cywilnych, „Państwo i Prawo" (dalej: PiP) 2008, nr 10; J. Dąbała, Traktatowe podstawy prawne wspótpracy sądowej w sprawach cywilnych w Unii Europejskiej, „Roczniki Nauk Prawnych” 2012, R. XXII, z. 3; R. Mańko, Europeanisation of civil procedure: Towards common minimum standards?, studium Biura Analiz Parlamentu Europejskiego, sygn. PE 559.499, Brussels 2015 http://ssrn.com/abstract=2617949, s. 9-15.

15 H.W. Micklitz, The EU as a Federal Order of Competences and the Private Law, [w:] The Question of Competence in the European Union, red. L. Azoulai, Oxford 2014, s. 132; J. Bełdowski, M. Zachariasiewicz, Nowy etap harmonizacji prawa umów w UE (cz. I), "Europejski Przegląd Sądowy" 2012, nr 6; R. Mańko, Contract Law and the Digital Single Market: Towards a new EU online consumer sales law?, studium Biura Analiz Parlamentu Europejskiego sygn. PE 568.322, Brussels 2015, http://ssrn.com/abstract=2660770, s. 5 (22.10.2015). 
zyjnego - na podstawie wyraźnej kompetencji, ograniczonej jednak tylko do aspektów transgranicznych. Te dwa ograniczenia, będące konsekwencją neofunkcjonalistycznego paradygmatu integracji, prowadzą oczywiście do fragmentaryczności unijnej aktywności legislacyjnej. Unijne prawo prywatne materialne reguluje jedynie te aspekty prawa, które można wyraźnie powiązać z funkcjonowaniem wspólnego rynku (np. prawo umów konsumenckich), a unijne prawo procesowe ogranicza się do kwestii jurysdykcji międzynarodowej oraz procedur transgranicznych. Jedynie $\mathrm{w}$ dziedzinie prawa prywatnego międzynarodowego kompetencja ustawodawcy unijnego jest zupełna i istnieją podstawy traktatowe do całkowitego uregulowania tej dziedziny prawa na poziomie Unii.

Istniejąca sytuacja spotkała się z krytyką w nauce prawa. Jak pisze R. Zimmermann: „Niekorzystne i niebezpieczne skutki selektywnego i nieskoordynowanego charakter prawa jednolitego pochodzącego z Unii Europejskiej są dziś oczywiste. $W$ odniesieniu do dyrektyw nastąpiła tendencja do tworzenia »wysp prawa jednolitego na morzu prawa krajowego, ale również szerokich obszarów, co do których trudno często stwierdzić, czy stanowią one część wybrzeża, czy morza otwartego, tj. czy podlegają one prawu jednolitemu, czy też prawu krajowemu« [H. Kötz]. Na poziomie krajowych systemów prawnych dyrektywy unijne dodały jeszcze jeden poziom złożoności"16. Tomasz Giaro dodaje pesymistycznie, że: „W wyniku punktowych interwencji prawa wspólnotowego dekodyfikacja systemów narodowych będzie się zapewnie pogłębiać, prowadząc do »dezintegracji przez harmonizację"17.

Jednym $z$ aspektów systemowości jest ścisły podział na prawo publiczne i prywatne. Podział taki nie jest jednak brany pod uwagę przez ustawodawce europejskiego ${ }^{18}$. Odmiennie niż np. w Polsce, gdzie kodyfikacją prawa prywatnego zajmuje się wyspecjalizowana Komisja Kodyfikacyjna Prawa Cywilnego, $\mathrm{w}$ Unii ustawodawstwo z zakresu prawa prywatnego tworzone jest łącznie z prawem publicznym, np. w zakresie prawa ochrony konsumenta czy wspólnego rynku.

Ponadto, w ramach neofunkcjonalnego podejścia, systemy prawne państw członkowskich narażone są na ciągły napływ "przeszczepów prawnych" z prawa Unii (niejednokrotnie inspirowanych jednym lub kilkoma systemami

16 R. Zimmermann, Prawo rzymskie a harmonizacja prawa prywatnego w Europie, "Nowa Europa” (dalej: NE) 2008, t. 11, s. 186; Por. R. Mańko, European Private Law - In Pursuit of Unity, „Przegląd Prawniczy UW" 2003, R. II, z. 1-2, s. 120-121; idem, Prawo prywatne w Unii Europejskiej. Perspektywy na przyszłość, Warszawa 2004, s. 13-26.

17 T. Giaro, Czy w przewidywalnej przyszłości powstanie europejskie prawo zobowiąan̆ , Forum Prawnicze” (dalej: FP) 2010, nr 1, s. 88. Por. J. Helios, op. cit., s. 102-113.

18 Por. J. Helios, op. cit., s. 85-86. 
prawnymi ${ }^{19}$ ). Jak wskazuje M. Loos, tego rodzaju przeszczepy prawne powodują „»irytację « istniejącego prawa: podważają jednolitość krajowego systemu prawnego (...), a skutki są często całkowicie nieprzewidywalne. Wynika stąd, że ustawodawstwo europejskie podważa spójność całego krajowego systemu prawnego" 20 .

Idea integracji funkcjonalnej przekłada się ponadto na funkcjonalistyczne podejście do prawa, które jest przeciwieństwem tradycyjnego podejścia systemowego ${ }^{21}$. Poszczególne akty prawne, w szczególności w zakresie prawa materialnego, regulują prawo prywatne $\mathrm{w}$ sposób wybiórczy, w oderwaniu od klasycznej systematyki prawa prywatnego. Nie ma więc np. dyrektywy o czynnościach prawnych czy dyrektywy o zobowiązaniach umownych, albo choćby dyrektywy o wadach oświadczenia woli, ale jest za to dyrektywa o niedozwolonych postanowieniach umownych ${ }^{22}$, o sprzedaży konsumenckiej ${ }^{23}$, czy tzw. dyrektywa o prawach konsumentów ${ }^{24}$, która pomimo szeroko sformułowanego tytułu $\mathrm{w}$ istocie reguluje jedynie prawa konsumentów w przypadku sprzedaży na odległość oraz poza lokalem przedsiębiorstwa. Funkcjonalistyczne podejście do prawa prywatnego prowadzi więc nieuchronnie do dekodyfikacji ${ }^{25}$.

Funkcjonalistyczne podejście do prawa ma też swój wpływ na jego dogmatykę. Prawo unijne posługuje się więc kategoriami oderwanymi od tradycyjnej dogmatyki prawa prywatnego, np. jego podmiotami są „,konsumenci”26 i „przedsiębiorcy” (a nie „osoby"27), nie ma mowy o nieważności czy bezskuteczności, lecz występuje pojęcie „niewiązania”"28. W tym względzie funk-

19 Przykładowo, reżim niedozwolonych postanowień umownych inspirowany był przede wszystkim uregulowaniami niemieckimi w tej materii. Por. K. Kańska, Ochrona ekonomicznych interesów konsumentów w prawie Unii Europejskiej na przyktadzie dyrektywy 93/13/EWG, [w:] Szkice z prawa Unii Europejskiej, red. E. Piontek, A. Zawidzka, t. II, Kraków 2013.

20 M.B.M. Loos, The Influence of European Consumer Law on General Contract Law and the Need for Spontaneous Harmonization, „European Review of Private Law” (dalej: ERPL) 2007, R. XV, z. 4, s. 522 .

21 C. Semmelmann, The Public-Private Divide in European Union Law or an Overkill of Functionalism, „Maastricht Faculty of Law Working Paper” nr 12/2012, http://ssrn.com/abstract=2056311, s. 13 (22.10.2015).

22 Dyrektywa 93/13.

23 Dyrektywa 99/44.

24 Dyrektywa 2011/83.

25 Por. W. Dajczak, Poszukiwanie nowego tadu prawa prywatnego w okresie jego dekodyfikacji i instrumentalizacji. Uwagi z perspektywy tradycji romanistycznej, [w:] Jednostka a państwo na przestrzeni wieków, red. J. Radwanowicz-Wanczewska, P. Niczyporuk, K. Kuźmicz, Białystok 2008; W. Dajczak, F. Longchamps de Bérier, Prawo rzymskie w czasach dekodyfikacji, FP 2012, t. 10.

26 Por. K. Kańska, Pojęcie konsumenta w Kodeksie cywilnym na tle tendencji europejskich, KPP 2014, nr 1, gdzie zwrócono uwagę na obcość pojęcia „konsument” z perspektywy europejskiej tradycji prawnej oraz na jego genezę w naukach ekonomicznych.

27 Por. M. Bartl, Internal Market Rationality..., op. cit., s. 581-582.

28 Tak w dyrektywie 93/13/EWG. 
cjonalizm przekłada się na instrumentalizację prawa, traktowanego jako narzędzie realizacji celów ekonomicznych ${ }^{29}$ (o czym będzie mowa niżej).

Idea systemowości prawa jest to założenie, wedle którego prawo stanowi system (albo przynajmniej nauka i orzecznictwo powinny dążyć do uczynienia mu takiego kształtu), a zatem układ logicznie powiązanych norm, które są niesprzeczne i zupełne ${ }^{30}$. Idea systemowości prawa w kulturze unijnego prawa prywatnego jest niewątpliwie ideą recesywną, ustępującą $\mathrm{w}$ starciu $\mathrm{z}$ ideą neofunkcjonalizmu. Unijne prawo prywatne ujęte jest nie w logicznie uporządkowane kodeksy, ale składa się z mozaiki fragmentarycznych dyrektyw i rozporządzeń. Tym niemniej koncepcja skodyfikowania unijnego prawa prywatnego w postaci europejskiego kodeksu cywilnego lansowana była już od końca lat siedemdziesiątych XX w. ${ }^{31} \mathrm{Na}$ przełomie lat osiemdziesiątych i dziewięćdziesiątych wzbudziła zainteresowanie Parlamentu Europejskiego, a później, w początkach XXI w. - rozważała ją w swych komunikatach Komisja Europejska $^{32}$. Idea systemowości prawa w postaci jego kodyfikacji znalazła wielu zwolenników wśród doktryny unijnego prawa prywatnego, działającej na tym odcinku przy wsparciu Komisji Europejskiej. Praktycznym wyrazem tego zjawiska były działające od lat osiemdziesiątych XX w. grupy kodyfikacyjne ${ }^{33}$, spośród których należy wymienić Komisję Europejskiego Prawa Umów, Grupę Studyjną ds. Europejskiego Prawa Umów) oraz Grupę ds. Istniejącego Europejskiego Prawa Prywatnego (tzw. Grupę Acquis), a następnie konsorcjum dwu ostatnich grup w postaci Wspólnej Sieci Europejskiego Prawa Umów (Joint Network on European Private Law) ${ }^{34}$. Efektem prac każdej z grup były, ujęte $\mathrm{w}$ artykuły, projekty kodyfikacji unijnego prawa prywatnego ${ }^{35}$. Najważniejszy $\mathrm{z}$ nich to tzw. Wspólny system odniesienia ${ }^{36}$, przygotowany przez Wspólną Sieć Europejskiego Prawa Umów i w zamierzeniu stanowiący syntezę efektów prac wcześniejszych grup. Wspólny system odniesienia został opublikowany w 2009 r., a następnie opracowano do niego wielotomowy komentarz.

29 Por. M. Bartl, The Way We Do Europe: Subsidiarity and the Substantive Democratic Deficit, ELJ 2015, R. XXI, z. 1, s. 29-30.

30 Por. M. Stępień, Systemowość prawa Unii Europejskiej, Poznań 2008.

31 J. Helios, op. cit., s. 131 i nast.

32 Zob. R. Mańko, Instytucje UE wobec idei europejskiego kodeksu prawa prywatnego, „Przegląd Prawa Europejskiego" 2004, nr 2, http://ssrn.com/abstract=2193035 (22.10.2015). prawa europejskiego, "Journal of Modern Science" 2016, t. II, s. 112-115. Zob. stronę internetową grupy: http://www.copecl.org/ (22.10.2015)

Por. R. Mańko, Europejski kodeks cywilny - stan prac nad projektem i perspektywy dalszego rozwoju, „Studia Iuridica” 2004, t. XLIII, http://ssrn.com/abstract=2069256 (22.10.2015).

36 Principles, Definitions and Model Rules of European Private Law. Draft Common Frame of Reference (DCFR). Outline Edition, red. C. von Bar, E. Clive, H. Schulte-Nölke, Munich 2009, http://ec. europa.eu/justice/policies/civil/docs/dcfr_outline_edition_en.pdf (dalej: DCFR). Por. A. Wudarski, Wspólny System Odniesienia - na drodze do europejskiego kodeksu cywilnego?, [w:] Wspótczesne problemy w administracji publicznej. Wybrane zagadnienia, red. P. Chmielnicki i in., Częstochowa 2008. 
Nigdy jednak żaden $\mathrm{z}$ aktów prawnych opracowanych przez grupy nie stał się prawem obowiązującym ${ }^{37}$, co nie znaczy, że nie wywiera wpływu na ustawodawcę, sądownictwo i edukację prawniczą. Co więcej, projekty te cieszą się spory zainteresowaniem dogmatyki i są przedmiotem badań prowadzonych według takiego samego paradygmatu, jak badania prawa pozytywnego. Na koniec warto podkreślić, że obok idei unifikacji, zaproponowana została także koncepcja synchronizacji prawa prywatnego, postulująca uwzględnienie wzorów zbliżania kultur prawnych znanych z tzw. systemów prawa mieszanego ${ }^{38}$. Wydaje się, że ma ona wiele wspólnego z kulturową koncepcją harmonizacji w ujęciu M. Zirka-Sadowskiego ${ }^{39}$.

Podsumowując tę partię rozważań należy podkreślić, że w starciu (neo)funkcjonalizmu z ideą systemowości prawa niewątpliwie zwycięża ta pierwsza idea, niemniej jednak tendencji do nadawania unijnemu prawu prywatnemu charakteru systematycznego nie można pomijać.

\subsection{Pragmatyzm versus formalizm}

Idea formalizmu w prawie zakłada, że podstawowe znaczenie należy przyznać przepisom prawa pozytywnego, a rekonstrukcja norm prawnych powinna opierać się przede wszystkim na językowo-logicznej wykładni tych przepisów $^{40}$. Dalsze znaczenie należy przyznawać dyrektywom wykładni systemowej, a zupełnie wyjątkowo można uciekać się do wykładni celowościowej. Idea pragmatyzmu (wykładni) natomiast, zwanego też antyformalizmem, zakłada natomiast podejście przeciwne ${ }^{41}$. W procesie wykładni prawa należy przypi-

37 Co jednak należy uznać za pozytywne, por. bowiem trafną uwagę B. Sitka: „Nieskoordynowane działania w obszarze ujednolicania europejskiej przestrzeni prawnej, zwłaszcza poprzez jeszcze do niedawna zamierzone wprowadzenie europejskiego kodeksu cywilnego, bez odpowiedniego przygotowania środowiska prawniczego, mogą doprowadzić do wulgaryzacji prawa" (B. Sitek, Unifikować czy synchronizować..., s. 117). Por. także uwagi M. Zirka-Sadowskiego, który podkreśla, że „warunkiem wstępnym integracji porządków prawnych jest wspólne dla nich tło kulturowe, czyli wspólne kategorie myślenia prawnego, które unifikują prawotwórstwo i praktykę prawniczą, oraz stanowią ramy pojęciowe interpretacji prawniczej i rozumowań prawniczych" (M. Zirk-Sadowski, op. cit., s. 108).

B. Sitek, Unifikować czy synchronizować..., s. 118 i nast.

M. Zirk-Sadowski, op. cit., s. 115.

Por. T.C. Gray, Judicial Review and Legal Pragmatism,, "Wake Forest Law Review” 2003, R. XXXVIII; Z. Kühn, The Judiciary in Central and Eastern Europe: Mechanical Jurisprudence in Transformation?, The Hague, 2011, s. 67 i nast.; R. Mańko, The Impact of EU Membership on Private Law Adjudication in Poland: A Case Study of the Polish Supreme Court's Case Law on Unfair Terms in Consumer Contracts, [w:] Central European Judges Under the European Influence: The Transformative Power of the EU Revisited, red. M. Bobek, Oxford 2015, s. 77-80.

41 Por. M.W. Hesselink, The New European Legal Culture, Deventer 2001, s. 73; R. Mańko, "War of Courts" as a Clash of Legal Cultures: Rethinking the Conflict between the Polish Constitutional Tribunal and the Supreme Court Over 'Interpretive Judgments', [w:] Law, Politics, and the Constitution: New Perspectives from Legal and Political Theory, red. M. Hein i in., Frankfurt am Main 2014, s. 80-81. 
sać pierwszorzędne znaczenie społeczno-gospodarczym konsekwencjom przyjętego rozstrzygnięcia. W konsekwencji, na czoło wysuwa się wykładnia teleologiczna, mniejsze natomiast znaczenie mają formalistyczne dyrektywy wykładni, tj. wykładnia językowo-logiczna i systemowa.

Analiza orzecznictwa Trybunału ${ }^{42}$ wskazuje na dominację wykładni pragmatycznej ${ }^{43}$. Dotyczy to $\mathrm{w}$ równym stopniu unijnego prawa prywatnego, gdzie dyrektywy wykładni celowościowej przeważają nad wykładnią literalną. Szczególnie jaskrawym przykładem tego podejścia jest wykładnia dyrektywy o niedozwolonych postanowieniach umownych ${ }^{44}$. Trybunał, kierując się względami funkcjonalnymi, ale bez oparcia $w$ tekście dyrektywy, stworzył m.in. normę nakazującą sądom krajowym badanie wzorców umownych w umowach konsumenckich ex officio, a nawet przeprowadzenie w tym celu dochodzenia, niezależnie od krajowych unormowań proceduralnych (np. przewidujących zasadę skargowości i kontradyktoryjności) ${ }^{45}$. Innym przykładem pragmatycznej wykładni prawa jest orzeczenie Leitner ${ }^{46}$, w którym Trybunał powołał do życia odszkodowanie za zmarnowany urlop, nieprzewidziane $w$ dyrektywie o wycieczkach turystycznych, które uznał za niezbędne w celu zapewnienia tej dyrektywie "skuteczności”.

Idea formalizmu prawniczego jest więc niewątpliwie recesywna gdy chodzi o orzecznictwo Trybunału. Natomiast znaczącym formalizmem odznacza się stylizacja unijnych aktów prawnych, które znane są ze swej kazuistyki. Szczególnym przypadkiem jest tzw. nowy formalizm prawa umów, przewidujący niezwykle rozbudowane i kazuistycznie ujęte katalogi informacji, jakie przedsiębiorca ma przekazać konsumentowi ${ }^{47}$. Z przewagą pragmatyzmu nad formalizmem (oraz omówionej wyżej przewagi funkcjonalizmu nad systemowością) wiąże się atrofia dogmatyki prawa europejskiego ${ }^{48}$.

Jak zauważa M. Zirk-Sadowski, ETS „odgrywa tak doniosłą rolę w kształtowaniu prawa wspólnotowego, że uzaasadnione są przypuszczenia o użyteczności anglosaskiej doktryny 'judge made law' na gruncie prawa wspólnotowego". M. Zirk-Sadowski, op. cit., s. 105. 2015, s. 115 i nast.

Dyrektywa Rady 93/13/EWG z dnia 5 kwietnia 1993 r. w sprawie nieuczciwych warunków w umowach konsumenckich.

Zob. np. M. Grochowski, Obowiazki informacyjne w umowach z udziałem konsumentów a nadmierny formalizm prawa, [w:] Kierunki rozwoju europesjkiego prawa prywatnego. Wptyw europejskiego prawa konsumenckiego na prawo krajowe, red. M. Jagielska, Warszawa 2012.

Zjawisko to pozytywnie ocenia M. Zirk-Sadowski, pisząc, że: „Pozytywistyczna aparatu pojęciowa nie wyjaśnia (...) prawa europejskiego, a przede wszystkim jego dynamiczności i otwartości. (...) Nadmierne udoskonalenie aparatury pojęciowej, która miałaby na celu większe 'zobiektywizowanie' tego prawa, mogłoby się okazzać w rezultacie zgubne. Zachowanie dynamiczności tego dyskursu jest głównym zadaniem filozofii prawa europejskiego". M. Zirk-Sadowski, op. cit., s. 106. 


\subsection{Instrumentalizm versus autonomia}

Idea instrumentalizmu zakłada, że prawo jest jedynie środkiem do innego celu - społecznego, gospodarczego, czy politycznego ${ }^{49}$. Idea autonomii prawa zakłada natomiast, że prawo ma do zrealizowania własne cele, których nie można sprowadzić jedynie do celów społeczno-gospodarczych i politycznych. W unijnej kulturze prawa prywatnego można zdecydowanie mówić o instrumentalizacji prawa ${ }^{50}$. Jest to prostą konsekwencją dominacji paradygmatu neofunkcjonalnego, o którym była mowa wyżej. Prawo traktowane jest jako instrument integracji („integracja przez prawo" ${ }^{\prime 1}$ ), jako środek do budowania wspólnego rynku ${ }^{52}$, jako narzędzie do konstruowania „przestrzeni wolności, bezpieczeństwa i sprawiedliwości”. Jak pisze M.W. Hesselink: „narzędzie ustawodawcze $\mathrm{w}$ postaci dyrektyw oparte jest na instrumentalnym podejściu do prawa, które obce jest tradycyjnemu pojmowaniu prawa prywatnego. Tradycyjnie, prawo prywatne traktowane jest jako względnie apolityczne. Jednakże dzięki dyrektywom, prawo prywatne staję się w sposób otwarty narzędziem do osiągania celów politycznych, społecznych, gospodarczych i innych" ${ }^{\prime 53}$.

Brak jest natomiast odniesień do autonomicznych wartości prawa. O braku autonomii prawa najlepiej świadczy fakt, że podział na prawo publiczne i prywatne, fundamentalny dla autonomii tego ostatniego, jest $\mathrm{w}$ unijnej kulturze prawnej mocno zatarty, jeśli nie wręcz całkowicie zapoznany ${ }^{54}$. Ponadto, jak trafnie zauważył M. Zirk-Sadowski: „Prawo europejskie nie mieści się $\mathrm{w}$ tradycyjnej aparaturze pozytywizmu, opartej na ścisłym rozróżnianiu prawa i wszystkiego, co wobec niego zewnętrzne" ${ }^{\prime \prime 5}$.

\subsection{Technokratyzm versus demokratyzm}

Ideologia technokratyczna zakłada, że zarządzanie społeczeństwem można sprowadzić do rozwiązywania zaistniałych problemów przez ekspertów. Jak zauważa M. Ziętek: „Technokracja jako postać organizacji formalnej jest jedną

49 Por. B. Sitek, Od antropocentryzmu prawniczego do ekonomizacji prawa, [w:] Człowiek pomiędzy prawem a ekonomia $w$ procesie integracji europejskiej, red. G. Dammacco, B. Sitek, O. Cabaj, Olsztyn-Bari 2008, s. 66-78; B. Sitek, Prawo jako wartość. Rozważania o autonomii i ponadczasowości prawa w świetle zjawiska ponowoczesności, [w:] Człowiek - Prawo - Państwo. Księa jubileuszowa prof. Stanisława Leszka Stadniczenko, red. J. Jeżewski, A. Pawlak, Warszawa 2017, s. 898-899.

Por. M. Bartl, The Way We Do Europe..., s. 29-30.

51 Por. Integration Through Law Revisited: The Making of the European Polity, red. D. Augenstein, Ashgate, 2011.

52 Por. M. Zirk-Sadowski, op. cit., s. 98.

53 M. W. Hesselink, The New European Legal Culture, Deventer 2001, s. 37-38.

54 Por. C. Semmelmann, Theoretical reflections on the public-private distinction and their traces in European Union law, “Oñati Socio-Legal Series” 2012, R. II, z. 4, http://ssrn.com/abstract=2016077 (22.10.2015). 
z form biurokracji zorientowaną na efektywne rozwiązywanie określonych zadań nowoczesnego państwa za pomocą wyspecjalizowanej wiedzy naukowo-technicznej. (...) Decyzje technokratyczne uzasadniane są przede wszystkim poprzez kryterium skuteczności rozwiązania ze względu na założone cele oraz kryteria optymalizacyjne. (...) Technokracja najczęściej definiowana jest jako rządy ekspertów, wyposażonych $\mathrm{w}$ wyspecjalizowaną wiedzę naukowo-techniczną i zarządzających państwem na podstawie kryteriów czysto fachowych" 56 .

Integracja europejska była od samego początku oparta na idei technokratyzmu, której uosobieniem stała się Komisja Europejska ${ }^{57}$. Wywarło to swoje niewątpliwe piętno na unijnej kulturze prawa prywatnego.

W szczególności wiele aktów prawnych było przyjmowanych niejako ad hoc, $\mathrm{w}$ celu usunięcia zaistniałego problemu ${ }^{58}$. Czołowym przykładem prawotwórstwa technokratycznego i odpolitycznionego - jako przeciwieństwo prawotwórstwa demokratycznego i politycznego - był projekt Wspólnego europejskiego prawa sprzedaży (Common European Sales Law, CESL) ${ }^{59}$. Był on owocem wieloletniej pracy rozmaitych grup eksperckich, poczynając od samozwańczej (acz finansowanej przez KE) tzw. Komisji Lando, poprzez Grupę Badawczą von Bara, CoPECL - który opracował Wspólny System Odniesienia (w.s.o.), aż po "grupę ekspercką" powołaną bezpośrednio przez Komisję, która opracowała ostateczny projekt CESL, wniesiony następnie do Parlamentu przez Komisję ${ }^{60}$. W istocie treść projektu została przesądzona przez technokratów (ekspertów od prawa prywatnego, powołanych przez Komisję).

Zdaniem M. Ziętek: „O technokratycznym charakterze europejskich dyrektyw konsumenckich w pierwszej kolejności decyduje więc sposób powstawania tych regulacji. Europejskie dyrektywy tworzone są przez europejskich urzędników, nie pochodzą one z praktyki prawniczej, nie są także $\mathrm{w}$ inny sposób wypracowane przez środowisko prawnicze. $\mathrm{W}$ proces tworzenia tych norm uwikłani są wprawdzie przedstawiciele nauki i praktyki, jednak to europejscy urzędnicy są odpowiedzialni za ich ostateczny kształt. Regulacje te są częścią określonych programów politycznych UE, sposób powstawania dyrektyw jest nieodłącznie związany z procesem realizacji celów politycznych UE"61.

M. Ziętek, Europejskie prawo konsumenckie..., s. 276.

M. Bartl, Internal Market Rationality..., s. 576.

Przykładowo, dyrektywy o sprzedaży na odległość czy o sprzedaży obnośnej, odnoszące się do konkretnych, wąsko zakreślonych problemów obrotu.

Dokument nr COM(2011) 635 final.

Por. R. Mańko, Contract law..., s. 14-18.

M. Ziętek, Europejskie prawo konsumenckie..., s. 282. 
Diagnozę "technokratyczności” podejścia Komisji Europejskiej do prawa prywatnego stawiają badacze unijnego prawa prywatnego. I tak, przykładowo M.W. Hesselink stwierdził, że w Planie działania w sprawie europejskiego prawa umów z 2003 Komisja „przyjęła technokratyczne podejście do europejskiego prawa umów”, czego przejawem jest, w jego ocenie, „zlecenie grupie naukowców przygotowania tzw. wspólnego systemu odniesienia (...)"'62.

Przeciwieństwem podejścia technokratycznego jest podejście demokratyczne i polityczne do prawa prywatnego ${ }^{63}$. Postulat upolitycznienia dyskusji nad europejskim kodeksem cywilnym zgłosił swego czasu M.W. Hesselink ${ }^{64}$. Ułożył nawet w tym celu listę 50 „pytań politycznych, dotyczących europejskiego prawa umów, które mogłyby zostać przedłożone Parlamentowi Europejskiemu i innym zainteresowanym" ${ }^{\prime 65}$. Co ciekawe, pytania nie dotyczą kwestii, które prima facie wydawałyby się „polityczne” w potocznym znaczeniu tego słowa. Wręcz przeciwnie, pytania te mają raczej charakter "techniczny". Przytoczmy przykładowe pytania ${ }^{66}$ : "Czy na stronach umowy powinien spoczywać ogólny obowiązek współdziałania?” (pytanie 4); „Czy na stronach umowy powinien spoczywać ogólny obowiązek wzajemnego zawiadamiania się o zdarzeniach i okolicznościach, które mają znaczenie dla ich świadczeń?" (pytanie 5); „Czy strony powinny mieć prawo do przyznawania uprawnień osobom trzecim?" (pytanie 14).

Nie będzie chyba przesadą stwierdzenie, że odpowiedzi na tak sformułowane pytanie trudno uznać za "polityczne” w potocznym tego słowa znaczeniu, a udzielenie należycie uzasadnionych odpowiedzi na nie mogłoby nastręczać trudności nawet prawnikom. Rozpoczęcie demokratycznej dyskusji nad tymi zagadnieniami i to $\mathrm{z}$ udziałem nieprawników wydaje się pomysłem tyleż oryginalnym, co kontrowersyjnym.

Choć lista pytań ułożona przed ponad dekadą ${ }^{67}$ przez Hesselinka stanowi dziś jedynie interesującą historyczną ciekawostkę unijnej kultury prawa prywatnego, jej pojawienie się i reakcja na nią (tj. brak reakcji) są znamienne i potwierdzają tezę, iż polityczność oraz demokratyzm prawa prywatnego, jako idee inspirujące unijną kulturę prawa prywatnego, mają charakter niewątpliwie recesywny. Pojawiają się bowiem okazjonalnie w dyskursie prawniczym, niemniej jednak nie mają decydującego wpływu na kształt przepisów i orzecznictwa.

\footnotetext{
M.W. Hesselink, Polityczne aspekty europejskiego koeksu cywilnego, KPP 2006, R. XV, z. 2, s. 302.

M. Bartl, Internal Market Rationality..., s. 595-598.

M.W. Hesselink, Polityczne aspekty..., s. 330 i nast.

Ibidem, s. 334.

Ibidem, s. 334-340.

Angielski oryginał artykułu Hesselinka Polityczne aspekty... ukazał się w listopadzie 2004 r. na łamach poczytnego "European Law Journal". M.W. Hesselink, The Politics of a European Civil Code, ELJ 2004, R. X, z. 6.
} 
Do idei demokratyzmu w prawie umów M.W. Hesselink powrócił w niedawnym artykule ${ }^{68}$, w którym stawia tezę, iż normy prawa prywatnego muszą posiadać demokratyczną legitymizację, czym nie różnią się, jego zdaniem od norm prawa publicznego. Opierając się na myśli J. Habermasa, Hesselink postuluje, by treść norm prawa prywatnego ustalana była w demokratycznej debacie, w której wszystkie warstwy społeczeństwa będą wysłuchane. Nie sposób oprzeć się wrażeniu, że koncepcja Hesselinka jest utopijna, jako że zapoznaje agonistyczny charakter społeczeństwa, w którym interesy poszczególnych grup czy warstw nie mogą zostać ze sobą pogodzone w harmonijnej wizji wspólnoty komunikacyjnej69.

\section{Idee materialne}

\section{1. (Neo)liberalizm versus sprawiedliwość społeczna}

Faktem jest, że u podstaw ideowych Europejskiej Wspólnoty Gospodarczej leżała idea neoliberalna ${ }^{70}$. Na zdominowanie dyskursu naukowego eurocywilistyki przez neoliberalizm wskazują też U. Mattei i F. Nicola. Ich zdaniem celem rozwoju unijnego prawa prywatnego jest demontaż krajowych mechanizmów ochrony słabszej strony umowy, a także promowanie neoliberalnej wizji społeczeństwa przez koncepcję kontraktu ${ }^{71}$. W ich optyce „»[k]ontaktualizacja « przestrzeni prawnej i politycznej otworzyła $\mathrm{w}$ istocie nowe obszary dla neoliberalizmu, sugerując elastyczny porządek, $\mathrm{w}$ którym prawa i zabezpieczone pozycje zostają porzucone na rzecz logiki rynkowej"72. Tezy U. Mattei i F. Nicoli znajdują potwierdzenie $w$ analizach dogmatycznych. Przykładowo, holenderski cywilista M. Loos zwraca uwagę, że poziom ochrony przewidziany w prawie Unii jest niższy niż w wielu państwach członkowskich ${ }^{73}$. Także M. Bartl podkreśla rolę ideologii neoliberalnej $\mathrm{w}$ kształtowaniu unijnego prawa prywatnego, wskazując ponadto na znaczenie prowadzonych z ideologicznych pobudek procesów prywatyzacyjnych, które znacząco rozszerzyły zakres regulacji prawa prywatnego w Unii Europejskiej ${ }^{74}$.

M.W. Hesselink, Democratic contract law, "European Review of Contract Law" 2015, R. XI, z. 2.

Zob. C. Mouffe, Polityczność, Warszawa 2008. Por. M. Stambulski, M. Paździora, Co może dać nauce prawa polityczność? Przyczynek do przyszłych badań, „Archiwum Filozofii Prawa i Filozofii Społecznej" (dalej: AFPiFS) 2014, nr 1.

M.W. Hesselink, Europejskie prawo umów: kwestia ochrony konsumenta, obywatelstwa czy sprawiedliwości, NE 2008, 11 (7), s. 229 z powołaniem się na W. van Gerwena.

U. Mattei, F.G. Nicola, A „social dimension" in European private law? The call for setting a progressive agenda, "New England LR" 2006, R. XLI, z. 1, s. 30.

Ibidem, s. 30 .

M. Loos, The Influence..., s. 523.

M. Bartl, Internal Market Rationality..., s. 577, 597. Zob. także M. Bartl, C. Leone, Minimum Harmonisation after Alemo-Herron: The Janus Face of EU Fundamental Rights Review, "European Constitutional Law Review" 2015, R. XI. 
Z drugiej jednak strony, $\mathrm{z}$ perspektywy np. polskiego systemu prawnego, unijne prawo prywatne podniosło poziom ochrony konsumenta $\mathrm{w}$ wielu dziedzinach, np. w zakresie niedozwolonych postanowień umownych (gdzie ochrona istniała od 1990 r., jednak w zasadzie tylko na papierze) czy w dziedzinie umów zawartych na odległość (gdzie brak było wcześniejszych uregulowań). Znacząco rozbudowano, na nieznaną wcześniej skalę, zakres obowiązków informacyjnych przedsiębiorcy wobec konsumenta. Jednak np. w dziedzinie sprzedaży konsumenckiej poziom ochrony uległ obniżeniu i to pomimo faktu, że unijna dyrektywa z 1999 r. przewidywała minimalny poziom ochrony, a polski ustawodawca mógł swobodnie chronić konsumenta w większym zakresie, z czego jednak nie skorzystał.

Przejawem dominacji idei liberalnych może być podejście Komisji Europejskiej. W swym „Planie działania” z 2003 r. pisała ona, że w pracach nad systematyzacją europejskiego prawa umów „swoboda umów powinna być zasadą przewodnią; ograniczenia powinny być przewidziane tylko tam, gdzie może to zostać uzasadnione w sposób przekonujący"75. Komentując te słowa, M.W. Hesselink zauważył, że „pozostawiają [one] bardzo niewiele wątpliwości: Komisja w sposób otwarty opowiedziała się na neoliberalnym wspólnym systemem odniesienia. (...) Jeżeli kodeks oparty na takim wspólnym systemie odniesienia miałbym zastąpić prawa umów państw członkowskich (...) oznaczałoby to radykalną zmianę stanu prawnego. Nie tylko współcześnie uznaje się, że prawo prywatne oparte jest na obu (sprzecznych ze sobą) zasadach autonomii i solidaryzmu, ale także $\mathrm{w}$ większości państw członkowskich nie można poważnie traktować zasady swobody umów jako zasady przewodniej (...)"76. Zdaniem Hesselinka, preferencja Komisji dla idei (neo)liberalnych nie wynika ani $\mathrm{z}$ prawa piewotnego Unii, ani nawet $\mathrm{z}$ idei wspólnego rynku ${ }^{77}$.

Oceniając wpływ idei neoliberalizmu na wspomniany wcześniej Wspólny system odniesienia, M.W. Hesselink zauważył, że w istocie rozwiązania przyjęte w w.s.o. są bardziej liberalne, niż te przyjęte wcześniej w „Zasadach europejskiego prawa umów" Komisji Lando ${ }^{78}$. Niemniej jednak, jego zdaniem, w.s.o. jest i tak mniej liberalny niż klasyczne kodeksy cywilne.

Opierając się na powyższym można ostrożnie przyjąć, że w unijnej kulturze prawa prywatnego podejście liberalne do prawa umów jest jednak dominujące. Próbę rewindykacji idei sprawiedliwości społecznej w dyskursie unijnego prawa prywatnego podjął w 2004 r. zespół badaczy unijnego prawa prywatnego pod kierunkiem M.W. Hesselinka. W skład zespołu, który określił się

75 Bardziej spójne europejskie prawo umów: Plan działania, $\operatorname{COM(2003)68~final,~} 12$ lutego 2003 r., ust. 62 (przekład polski za: M.W. Hesselink, Polityczne aspekty..., s. 321-322).

M.W. Hesselink, Polityczne aspekty..., s. 322.

77 Ibidem.

78 M.W. Hesselink, CFR and Social Justice, "Centre for the Study of European Contract Law Working Paper Series" 2008, nr 8, s. 41. 
jako Grupa Studyjna ds. Sprawiedliwości Społecznej w Europejskim Prawie Umów (Study Group on Social Justice in European Contract Law), weszli znaczący przedstawiciele nauki europejskiego prawa prywatnego (m.in. H. Collins, S. Grundmann, C. Joerges, B. Lurger czy T. Wilhelmsson). Efektem prac Grupy był "manifest”, który został opublikowany na łamach „European Law Journal” w 2004 r. pod tytułem Sprawiedliwość społeczna w europejskim prawie umów: manifest ${ }^{79}$. Dokument ten, po przeprowadzeniu dogłębnej krytyki dotychczasowej praktyki tworzenia unijnego prawa umów, którą określono mianem technokratycznej, rozwinął „Program sprawiedliwości społecznej dla europejskiego prawa umów"80.

W konkluzjach swoich rozważań autorzy „manifestu” wskazali, że „program stworzenia europejskiego systemu prawa umów musi stwarzać gwarancje ukierunkowanai procesu politycznego na realizację ideałów sprawiedliwości społecznej. Postrzeganie tego procesu jako prostego mechanizmu budowy rynku jest błędem, ponieważ podstawowe zasady rządzące sprawiedliwością społeczną $w$ porządku rynkowym określa prawo prywatne. (...) Stworzenie właściwych rama prawnych wymaga (...) procesu, który nie jest jedynie technokratyczną próbą harmonizacji czy unifikacji. Proces ten powinien mieć raczej charakter politycznego dialogu na temat metod pogodzenia podstawowych wartości, którego wyniki będą akceptowalne w drodze mechanizmów demokratycznych" ${ }^{\prime 1}$.

Poglądy wyrażone w "manifeście”, także z uwagi na fakt, iż w Grupie Studyjnej, która go przygotowała, zasiedli czołowi przedstawiciele doktryny unijnego prawa prywatnego, wywarły swój wpływ na przepisy Wspólnego systemu odniesienia. Jego twórcy zidentyfikowali cztery zasady naczelne swojego projektu. Są to: wolność (freedom), bezpieczeństwo (security), sprawiedliwość (justice) oraz efficiency (efektywność) ${ }^{82}$. Co prawda mowa jest o „sprawiedliwości" bez przymiotnika "społeczna", jednak wydaje się, że użyte pojęcie obejmuje także sprawiedliwość społeczną, o której mowa była w Manifeście z 2004 r.

Oceniając treść w.s.o. z perspektywy realizacji zasady sprawiedliwości społecznej, M.W. Hesselink zwrócił uwagę na rolę klauzul generalnych - dobrej wiary (good faith), dobrych obyczajów (good morals), rozsądku (reasonableness) i uczciwości (fairness) w tekście projektu jako na potencjalnych trajektoriach

79 Tytuł oryginału: Social Justice in European Contract Law: A Manifesto (ELJ 2004, t. X, z. 6). Przekład polski artykułu Sprawiedliwość społeczna w europejskim prawie umów: manifest w: „Nowa Europa” 2008, nr 11(7)

Manifest Sprawiedliwość społeczna..., s. 296 i nast.

Ibidem, s. 315.

DCFR, s. 60. Można odnieść wrażenie, że dobierając zasady przewodnie w.s.o. właśnie w takim składzie i w takiej kolejności, jego twórcy chcieli nawiązać do koncepcji unijnej „Przestrzeni wolności, bezpieczeństwa i sprawiedliwości" (pojęcia wprowadzonego Traktatem Amsterdamskim z 1992 r.), bardziej niż do tradycji prawa prywatnego. 
nasycania w.s.o. sprawiedliwością społeczną $\mathrm{w}$ toku jego wykładni ${ }^{83}$. Autor ten wskazał, że klauzule generalne były, w historycznym rozwoju prawa, wykorzystywane przez sądy, aby tworzyć normy prawne inspirowane względami sprawiedliwości społeczneje ${ }^{84}$.

Twórcy w.s.o. wyjaśniając rolę sprawiedliwości w projekcie, wskazali, że ma ona znaczenie uniwersalne, lecz może pozostawać $\mathrm{w}$ konflikcie $\mathrm{z}$ pozostałymi zasdadami naczelnymi ${ }^{85}$. Analizując bliżej rozumienie "sprawiedliwości" przez twórców w.s.o. należy wskazać, że „sprawiedliwość społeczna” jest jednym z elementów definiowanej przez nich sprawiedliwości. Tę ostatnią definiują oni za pomocą następującej definicji tetycznej: „zapewnianie, by podobne było traktowane podobnie; nie pozwalanie ludziom, by polegali na swoim bezprawnym, nieuczciwym lub nierozsądnym (unreasonable) postępowaniu; nie pozwalanie ludziom, by czerpali nienależne korzyści ze słabości, nieszczęścia (misfortune) lub sympatii (kindness) innych ludzi; nieformułowanie rażąco nadmiernych żądań (grossly excessive demands); pociąganie ludzi do odpowiedzialności za konsekwencje ich działań oraz niebezpieczeństw (risks), które sami wytworzyli. Sprawiedliwość może także odnosić się do sprawiedliwości ochronnej (protective justice) - gdzie udzielana jest ochrona, czasem w spsoób ogólnie prewencyjny, osobom znajdującym się w słabym lub podatnym na skrzywdzenie (vulnerable) położeniu"86. Nie wdając się w szczegółowe, dogmatyczne analizy w.s.o. należy wskazać, że aspekty sprawiedliwości społecznej zostały w nim w określonym zakresie uwzględnione.

\subsection{Konsumeryzm versus obywatelskość}

Idea konsumeryzmu zakłada, że podstawowym celem człowieka, decydującym o jego tożsamości jest nabywanie i konsumowanie dóbr i usług ${ }^{87}$. W perspektywie ideologii konsumeryzmu zadaniem ustawodawcy jest stworzenie ram prawnych dla bezpiecznej i spokojnej konsumpcji. Idąc dalej, prawo może być instrumentalizowane w celu zachęcania do konsumpcji. W tej właśnie perspektywie należy widzieć np. przepisy unijne pozwalające konsumentom na dyskrecjonalne odstąpienie od umowy (tj. bez żadnego powodu) ${ }^{88}$. De facto, każda transakcja konsumencka, objęta reżimem konsumenckiego odstąpienia od umowy, staje się sprzedażą na próbę. Niewątpliwie, takie uregulowania mają swój cel ochronny (ochrona przed nieuczciwym sprzedawcą, wysyłają-

\footnotetext{
83 M.W. Hesselink, CFR..., s. 43-50.

84 Ibidem, s. 43.

85 DCFR, s. 84

86 DCFR, s. 84.

87 Por. Z. Bauman, Konsumowanie życia, Warszawa 2009.

88 Zob. art. 9 dyrektywy 2011/83.
} 
cym celowo towar wadliwy), niemniej jednak nie można oprzeć się wrażeniu, że gdyby chodziło tylko o ochronę konsumenta przed nieuczciwym przedsiębiorcą wystarczyłaby możliwośc odstąpienia od umowy w razie wady rzeczy sprzedanej. Dlatego można stwierdzić, że u podstaw omawianych uregulowań leżą idee właściwe dla konsumeryzmu.

Zdaniem R. Zimmermanna, konsumenckie prawo odstąpienia podważa $\mathrm{w}$ istocie zasadę pacta sunt servanda i powinno zostać ograniczone do przypadków rzeczywiście uzasadnionych względami racjonalnej polityki prawa ${ }^{89}$. M. Ziętek zauważa, że: „Prawo ochrony konsumenta ma także na celu pobudzić aktywność ekonomiczną samych konsumentów. Centralną figurą europejskiego prawa konsumenckiego jest »wyedukowany « konsument (...), który zna swoje prawa i odważnie wyrusza na podbój obcych rynków. Świadomość istnienia podobnych regulacji we wszystkich krajach europejskiech (...) ma zniszczyć $\mathrm{w}$ konsumencie bariery psychiczne przed kupowaniem $\mathrm{w}$ obcych krajach [a także] zapewnić mu komfort psychiczny i zachęcać do aktywności konsumenckiej"90. W świetle powyższego M. Ziętek trafnie konkluduje, że ochrona konsumenta przez UE jest „czynnikiem mającym pobudzić popyt (...), a tym samym prodkucję, czyli zapewnić wyższy wzrost gospodarczy"191. Konsument zostaje zatem sprowadzony do roli środka, a jego ochrona nie jest celem samym W sobie ${ }^{92}$.

Podobnego zdania jest M.W. Hesselink, który zauważa, że „zarówno z historii ochrony konsumenta w Europie, jak i z niedawnych dokumentów politycznych wynika, że pełni zaufania konsumenci traktowani są przez Wspólnotę Europejską - by użyć Kantowskiego sformułowania - jako środek do celu, jakim jest stworzenie prawidłowo funkcjonującego rynku wewnętrznego" ${ }^{\prime 93}$. Autor ten dodaje, że, jego zdaniem, założenie przyjmowane przez Komisję „polega na tym, iż ufni konsumenci będą bardziej skłonni oddawać się ponadgranicznym zakupom. To dorpowadzi do większego wzrostu gospodarczego (...). Dlatego ochrona konsumenta staje sie ochroną rynku"94. Zdaniem Hesselinka, rozbudowa obowiązków informacyjnych w unijnych dyrektywach jest przejawem ekonomistycznego myślenia o konsumencie, tj. założenia, że skutkiem zawodności rynku (market failure) jest brak informacji po stronie konsumenta ${ }^{95}$.

89 W. Dajczak, R. Zimmermann, Wywiad z Reinhardem Zimmermannem, FP 2011, nr 1(3), s. 10-11.

M. Ziętek, Europejskie prawo konsumenckie..., s. 283.

Ibidem.

Por. Sprawiedliwość społeczna..., s. 290: „Komisja w praktyce zwykle przedstawia środki ochrony konsumentów nie jako instrumenty wspomagające ochronę słabszej strony, lecz jako instrumenty korygujące rynek, które mają zapobiegać zakłóceniom konkurencji rynkowej."

M.W. Hesselink, Europejskie prawo umów..., s. 223.

Ibidem, s. 224.

95 Ibidem, s. 224-225. 
Postrzeganie osoby ludzkiej w wąskiej perspektywie ideologii konsumerystycznej skutkuje tym, że pomijane są takie wartości, jak „godność, wolność, równość, solidarność, pluralizm czy sprawiedlowość" ${ }^{\prime \prime 6}$.

Co prawda ochrona konsumenta została podniesiona do rangi prawa podstawowego w Karcie praw podstawowych UE (która od 2009 r. jest prawnie wiążąca, mając rangę aktu prawa pierwotnego), jednakże należy pamiętać, że prawo to nie ma charakteru zaskarżalnego, lecz jest jedynie dyrektywą polityki unijnej, a zatem lex imperfecta97. Ewa Łętowska twierdzi w tym kontekście, że konsument jest obecnie w Unii „”kkochany dla siebie samego «, staje się samoistnym celem działań integracyjnych, prowadzonych ze względu na polepszenie jego kondycji (...)" ${ }^{\prime \prime 8}$. Czy jest tak jednak w istocie? Rację ma raczej M. Ziętek, która zauważa, że: „»Miłość« ta jednak nie jest całkiem bezinteresowna: konsument jest chroniony po to, by patologie obrotu detalicznego w społeczeństwie konsumpcyujnym nie doprowadziły do jego autodestrukcji. Konsument jest chroniony, bo jest to pożyteczne z punktu widzenia zapewnienia "zrównoważonego" rozwoju"99. Na poparcie tej tezy M. Ziętek przytacza framgment ze Strategii Polityki Konsumenckiej z 2007 r. ${ }^{100,}$, w którym Komisja otwarcie przyznaje, że „Dobrobyt konsumentów leży u podstaw dobrze funkcjonujących rynków".

Z poglądem M. Ziętek należy się zgodzić. Także w późniejszych dokumentach programowych, np. w strategii Jednolitego Rynku Cyfrowego, możemy odnaleźć poglądy, które potwierdzają tezę, że unijna „miłość do konsumenta" nie jest bezinteresowna, jak chciałaby E. Łętowska, lecz - zgodnie z tezą M. Ziętek - pozostaje instrumentalnie podporządkowana potrzebom kapitalizmu. Wypada podkreślić, że właśnie $\mathrm{w}$ ramach realizacji Strategii Jednolitego Rynku Cyfrowego dla Europy ${ }^{101}$ zostały przedstawione nowe projekty dyrektyw o sprzedaży konsumenckiej oraz o dostarczaniu treści cyfrowych, które zastąpiły niechciany projekt CESL, który po trzech latach $\mathrm{w}$ legislacyjnej zamrażarce został de facto wycofany. Przyjrzyjmy się fragmentom, które dotyczą konsumenta:

„Aby zbudować zaufanie konsumentów do transgranicznych zakupów w internecie, konieczne są..." (s. 4).

„Konsumenci (...) nie biorą w większym stopniu udziału w transgranicznym handlu elektroniczny m.in. ze względu na..." (s. 4).

96 Ibidem, s. 226.

97 Por. M. Ziętek, Europejskie prawo konsumenckie..., s. 284.

98 E. Łętowska, Europejskie prawo umów konsumenckich, Warszawa 2002, s. 12.

99 M. Ziętek, Europejskie prawo konsumenckie..., s. 284.

$100 \operatorname{COM}(2007) 99$ final.

$101 \operatorname{COM}(2015) 192$ final. 
„Odmienność przepisów prawa ochrony konsumenta i prawa umów w 28 państwach członkowskich zniechęca firmy do handlu transgranicznego i uniemożliwia konsumentom skorzystanie $\mathrm{z}$ najbardziej konkurencyjnych ofert i z pełnego zakresu oferty w internecie" (s. 4).

„Konsumenci w UE mogliby co roku zaoszczędzić 11,7 mld EUR, gdyby kupując $w$ internecie, mieli dostęp do pełnej gamy produktów i usług oferowanych w UE" (s. 4).

Komisja nie bierze jednak pod uwagę, że nadmierna oferta może skłonić konsumentów do większych zakupów, a co za tym idzie, zamiast oszczędności, będą wieksze wydatki...

Martijn Hesselink postawił swojego czasu tezę, że dla strony umowy ma znaczenie, czy jest ona traktowana ,jako konsument, jako obywatel, czy jako osoba" ${ }^{\prime 102}$. Mówiąc językiem filozoficznym, istotne jest, czy do jakiej formy podmiotowości jednostka jest interpelowana ${ }^{103}$. Z tym poglądem wypada się zgodzić. Nie jest bez znaczenia, czy „jesteśmy ludźmi czy tylko konsumentami"104. Jak pisze Hesselink: „Prawo cywilne tradycyjnie zwraca się do ludzi jako do 'osób', dzięki czemu prawo umów jest w naturalny sposób kwestią sprawiedliwości w najszerszym możliwym znaczeniu. Idzie o istotną różnicę pomiędzy traktowaniem ludzi jako konsumentów, którzy mogą korzystać z ochrony, gdy zawiedzie rynek wewnętrzny, a traktowaniem ich jako jednostkowych obywateli, którym przysługują prawa podstawowe" ${ }^{105}$. Jego zdaniem identyfikowanie przez Komisję obywatelstwa europejskiego z ochroną konsmenta jest „poważnym błędem politycznym i moralnym"106.

Jak wskazuje jednak M.W. Hesselink, „o ile ustawodawstwo w dziedzinie prawa umów oparte na polityce ochrony konsumenta posiada niewątpliwą podstawę prawną, o tyle żaden $\mathrm{z}$ artykułów części o obywatelstwie w traktacie ani żaden inny przepis trataktatu (ani nawet nie karta nicejska [praw podstawowych - R.M.]) nie wydają się zapewniać podstawy do wydania przepisów (nie mówiąc już o kodeksie) dotyczących europejskiego prawa umów traktowanego jako kwestia europejskiego obywatelstwa"107. Innymi słowy, na przeszkodzie stworzenia „obywatelskiego" prawa prywatnego, traktującego człowieka nie tylko w perspektywie idei konsumeryzmu, ale w perspektywie całościowej jako podmiotu polis, stoi neofunkcjonalistyczna konstrukcja samej Unii, pojmo-

102 M.W. Hesselink, Europejskie prawo umów: kwestia ochrony konsumenta, obywatelstwa czy sprawiedliwości, NE 2008, nr 11 (7), s. 221.

103 R. Mańko, Pojęcie interpelacji ideologicznej a krytyczny dyskurs o prawie, AFPiFS 2004, nr 1.

104 M.W. Hesselink, Are we human beings or mere consumers, „European Voice” 18.10.2006 r., http:// www.politico.eu/article/are-we-human-beings-or-mere-consumers/ (14.10.2015).

105 Ibidem.

106 Ibidem.

107 M.W. Hesselink, Europejskie prawo umów..., s. 231-232. 
wanej jako podmiot realizujący w sposób technokratyczny określone, powierzone jej funkcje. Inna sprawa, czy pożądane byłoby - jak postuluje Hesselink ${ }^{108}$ - by faktycznie Unię w taką kompetencję wyposażać.

\subsection{Integracja versus suwerenność narodowa}

Stanowienie prawa stanowiło $\mathrm{w}$ europejskiej tradycji prawnej domenę suwerena. Nawet obowiązywanie Corpus Iuris Civilis wywodzono z decyzji suwerena, a to ze względu na założenie, że Cesarstwo Rzymskie Narodu Niemieckiego jest prawnym kontynuatorem starożytnego Imperium Romanum. Choć była to niewątpliwie fikcja prawna, to jednak świadczyła ona o przywiązaniu europejskiej wspólnoty prawniczej do idei powiązania kompetencji do tworzenia prawa $\mathrm{z}$ suwerennością.

Niewątpliwie od okresu wielkich kodyfikacji cywilnych związek prawa prywatnego z suwerennością uległ wzmocnieniu. Kodeks cywilny stał się odtąd symbolem jedności wspólnoty narodowej, jak miało to miejsce w przypadku kodeksu Napoleona, który zastąpił różnorodność systemów prawnych przedrewolucyjnej Francji. W Niemczech uchwalenie BGB świętowano hasłem Ein Volk, ein Reich, ein Recht ${ }^{109}$, które pokolenie później miało ulec złowrogiej mutacji.

Również członkowie Zespołu Badawczego Sprawiedliwości Społecznej w Europejskim Prawie Umów, spodziewając się uchwalenia unijnego kodeksu umów, zwracali uwagę, że "zapoczątkowanie procesu tworzenia i ewolucji prawa umów wyznaczy przełomowy moment w historii Europy. Porozumienie zawarte pomiędzy państwami narodowymi w przedmiocie wspólnych uregulowań prawnych będzie symbolizować - w sposób bardziej przejrzysty aniżeli jakikolwiek traktat czy konstytucja - powstanie ponadnarodowej formy rządów"110. Choć twierdzenie, że unijna kodyfikacja prawa umów symbolizowałaby ponadnarodową formę rządów bardziej niż traktaty unijne czy nawet Konstytucja UE należy uznać za mocno przesadzone, to jednak faktem pozostaje, że prawo prywatne posiada duży ładunek symboliczny, gdy idzie o tożsamość narodową (czy też postnarodową). Wiemy o tym z własnego doświadczenia historycznego, gdy jedną z pierwszych decyzji po odzyskaniu przez Polskę niepodległości było powołanie Komisji Kodyfikacyjnej Prawa Cywilnego z zamiarem unifikacji tej gałęzi prawa i usunięcia śladów panowania zaborców. Niemniej jednak fakt, iż członkowie Grupy Badawczej ds. Sprawiedliwości Społecznej w Europejskim Prawie Umów - będący równocześnie czołowymi przedstawicielami doktryny unijnego prawa prywatnego - uznali, że „[i]nicjatywy po-

108 Ibidem, s. 246.

109 R. Mańko, European Private Law..., s. 116.

110 Sprawiedliwość społeczna..., s. 275. 
dejmowane na gruncie prawa prywatnego wpisują się w mechanizm wzrastającej emancypacji Unii Europejskiej (...), zmierzającej w kierunku wykreowania podmiotu politycznego posiadającego własną konstytucję"111 jest wielce znaczący. Świadczy bowiem o przekonaniu żywionym przez doktrynę unijnego prawa prywatnego co do znaczenia podejmowanych działań na rzecz unifikacji, a być może kodyfikacji prawa prywatnego w Unii.

Przejawem ograniczania suwerenności narodowej jest już samo stanowienie norm prawa prywatnego przez Unię, a następnie ich autorytatywna wykładnia przez ETS. Jednym z najbardziej charakterystycznych przykładów w tym względzie jest wprowadzanie zasady inkwizycyjności i oficjalności do procedur cywilnych państw członkowskich w orzecznictwie ETS dotyczącym niedozwolonych postanowień umownych, o czym była mowa wyżej (w podrozdziale 2.2).

Innym przejawem daleko idącej ingerencji $\mathrm{w}$ suwerenność państwową $\mathrm{w}$ obszarze prawa prywatnego jest zniesienie exequatur, co nastąpiło początkowo w tzw. rozporządzeniach procesowych II generacji (europejskie postępowanie $\mathrm{w}$ sprawie drobnych roszczeń, europejski nakaz zapłaty, europejski tytuł wykonawczy), a następnie - z początkiem 2015 r. - w odniesieniu do ogółu orzeczeń cywilnych ${ }^{112}$. W chwili obecnej orzeczenie wydane przez sąd państwa obcego będącego członkiem UE występuje $\mathrm{w}$ obrocie niemal na takich samych zasadach, jak orzeczenie krajowe. Dłużnik ma co prawda możliwość podjęcia kroków mających na celu wstrzymanie wykonalności takiego orzeczenia, jednakże funkcjonuje ono na takich samych zasadach, jakby było zaopatrzone w klazulę wykonalności, a wierzyciel nie musi podejmować żadnych dodatkowych kroków, przechodząc natychmiast do egzekucji. Przy założeniu, że funkcją procedury exequatur było objęcie wyroku zagranicznego zgodą suwerennej władzy państwowej ${ }^{113}$ na uznanie i wykonanie takiego wyroku na terytorium krajowym, zniesienie wskazanej procedury stanowi bardzo istotny krok zmierzający do ograniczenia tej suwerenności i zbudowania jej kosztem „Europejskiej Przestrzeni Sprawiedliwości” w sprawach cywilnych"114.

Jeszcze innym przejawem ograniczania znaczenia suwerenności państwowej jest promowanie mechanizmów tzw. alternatywnego rozwiązywania sporów (alternative dispute resolution, ADR) w aktach prawnych Unii Europejskiej. Istotą mechanizmów ADR jest wyłączanie spraw spod wymiaru sprawiedliwości (sprawowanego w imię suwerena) i przekazywanie ich „sprawiedliwości prywatnej" - rozmaitym panelom ADR, prowadzonym przez podmioty pry-

111 Ibidem, s. 281.

112 Por. R. Mańko, Europeanisation of civil procedure..., s. 3-8.

113 Ibidem, s. 26.

114 Por. P. Grzegorczyk, Nowy fundament europejskiego prawa procesowego cywilnego: jurysdykcja krajowa, zawistość sprawy oraz uznawanie $i$ wykonywanie orzeczen $w$ sprawach cywilnych $i$ handlowych wedtug rozporządzenia Rady i Parlamentu Europejskiego nr 1215/2012 (Bruksela Ia), cz. 2, „Przegląd Sądowy” 2014, R. XXIII, z. 8. 
watne. Unia otwarcie popiera tego rodzaju mechanizmu, szczególnie w dziedzinie sporów konsumenckich, gdzie niedawno uchwalono dwa nowe akty prawne ${ }^{115}$.

Z drugiej jednak strony idea suwerenności - wyrażana w unijnym dyskursie za pomocą idei pomocniczości (subsydiarności) daje o sobie znać w unijnej kulturze prawa prywatnego. Jej przejawami są w szczególności zablokowanie idei kodyfikacji unijnego prawa prywatnego, z której Komisja się ostatecznie wycofała, pozostawiając w.s.o. „w zamrażarce”; odejście od harmonizacji totalnej (maksymalnej) prawa konsumenckiego ${ }^{116}$, a ostatnio ostra krytyka, jakiej poddany został projekt Wspólnego prawa sprzedaży przed niektóre parlamenty krajowe ${ }^{117}$ oraz jego wycofanie przez Komisję Europejską ${ }^{118}$.

\section{Podsumowanie}

Przeprowadzona analiza pozwoliła na wstępne określenie ideowych podstaw unijnej kultury prawa prywatnego. Pośród idei formalnych ujawniła się dominacja neofunkcjonalizmu nad systemowością prawa, pragmatyzmu nad formalizmem, instrumentalizmu nad autonomią oraz technokratyzmu nad demokratyzmem. Pośród idei materialnych zaznaczyła się dominacja liberalizmu nad sprawiedliwością społeczną, konsumeryzmu nad postrzeganiem jednostek jako obywateli oraz dominacja idei integracji nad ideą suwerenności narodowej. Okazało się też, że poszczególne idee i ich realizacje pozostają ze sobą w ścisłym związku. W szczególności neofunkcjonalny paradygmat integracji, przekładający się na funkcjonalistyczne podejście do prawa niewątpliwie sprzyja dominacji pragmatyzmu nad formalizmem oraz instrumentalizmu nad autonomią. Z kolei technokratyczna natura procesu integracji także wzmacnia instrumentalizm i pragmatyzm.

Gdy chodzi natomiast o idee materialne, widoczne są związki pomiędzy neoliberalizmem a konsumeryzmem. Można też wskazać na powiązania idei formalnych i materialnych, a w szczególności na ścisły związek pomiędzy

115 Dyrektywa 2013/11/UE z dnia 21 maja 2013 r. w sprawie alternatywnych metod rozstrzygania sporów konsumenckich; rozporządzenie (UE) nr 524/2013 z dnia 21 maja 2013 r. w sprawie internetowego systemu rozstrzygania sporów konsumenckich.

116 O zjawisku harmonizacji totalnej (makysmalnej) zob. A. Kunkiel-Kryńska, Metody harmonizacji prawa konsumenckiego w Unii Europejskiej $i$ ich wptyw na procesy implementacyjne, Warszawa 2013. W okresie, gdy powstała monografia A. Kunkiel-Kryńskiej, metoda harmonizacji totalnej wydawała się dominująca. Jednakże dyrektywa 2011/83 o prawach konsumentów, która jest aktem harmonizacji totalnej (niepozostawiającej państwom członkowskim swobody przy wdrożeniu) zastąpiła jedynie 2 dyrektywy, a nie 8 , jak pierwotnie planowano. Zaś dyrektywa o kredytach hipotecznych $(2014 / 17)$ jest dyrektywą harmonizacji minimalnej.

117 Por. R. Mańko, Contract law..., s. 17, przyp. 75.

118 Załącznik nr 2 do dokumentu COM(2014)910 final, s. 12, poz. 60. 
dominacją technokratycznego paradygmatu unijnego prawa prywatnego nad demkratyzmem z jednej strony, a dominacją podejścia konsumerystycznego nad postulowanym w niektórych kręgach podejście obywatelskim. W kontekście zaś całokształtu projektu europejskiego nie dziwi zasygnalizowana dominacja idei integracji nad ideą suwerenności narodowej.

\section{Bibliografia}

Bartl M., Internal Market Rationality, Private Law and the Direction of the Union: Resuscitating the Market as the Object of the Political, "European Law Journal" 2015, R. XXI, z. 5.

Bartl M., The Way We Do Europe: Subsidiarity and the Substantive Democratic Deficit, "European Law Journal" 2015, R. XXI, z. 1.

Bartl M., Leone C., Minimum Harmonisation after Alemo-Herron: The Janus Face of EU Fundamental Rights Review, "European Constitutional Law Review" 2015, R. XI.

Bauman Z., Konsumowanie życia, Warszawa 2009.

Bełdowski J., Zachariasiewicz A.M., Nowy etap harmonizacji prawa umów w UE (cz. I), „Europejski Przegląd Sądowy” 2012, nr 6.

Całus A., Umocowanie do zbliżania prawa prywatnego państw członkowskich w prawie Unii Europejskiej, [w:] Europeizacja prawa prywatnego, red. M. Pazdan i in., Warszawa 2008.

Dajczak W., Poszukiwanie nowego ładu prawa prywatnego w okresie jego dekodyfikacji i instrumentalizacji. Uwagi z perspektywy tradycji romanistycznej, [w:] Jednostka a państwo na przestrzeni wieków, red. J. Radwanowicz-Wanczewska, P. Niczyporuk, K. Kuźmicz, Białystok 2008.

Dajczak W., Longchamps de Bérier F., Prawo rzymskie w czasach dekodyfikacji, „Forum Prawnicze" 2012, t. 10.

Dajczak W., Zimmermann R., Wywiad z Reinhardem Zimmermannem, „Forum Prawnicze" 2011, nr 1(3).

Dąbała J., Traktatowe podstawy prawne wspótpracy sądowej w sprawach cywilnych w Unii Europejskiej, „Roczniki Nauk Prawnych” 2012, R. XXII, z. 3.

Giaro T., Czy w przewidywalnej przyszłości powstanie europejskie prawo zobowiązań, „Forum Prawnicze" 2010, nr 1.

Gray T.C., Judicial Review and Legal Pragmatism', "Wake Forest Law Review" 2003, R. XXXVIII.

Grochowski M., Obowiązki informacyjne w umowach z udziałem konsumentów a nadmierny formalizm prawa, [w:] Kierunki rozwoju europesjkiego prawa prywatnego. Wpływ europejskiego prawa konsumenckiego na prawo krajowe, red. M. Jagielska, Warszawa 2012.

Grødeland, Å.B., Miller, W.L. European Legal Cultures in Transition, Cambridge 2015. 
Grzegorczyk P., Nowy fundament europejskiego prawa procesowego cywilnego: jurysdykcja krajowa, zawisłość sprawy oraz uznawanie i wykonywanie orzeczeń w sprawach cywilnych $i$ handlowych według rozporządzenia Rady i Parlamentu Europejskiego nr 1215/2012 (Bruksela Ia), cz. 2, „Przegląd Sądowy” 2012, R. XXIII, z. 8.

Helios J., Prawo prywatne Unii Europejskiej ze stanowiska teorii prawa, Łódź 2014.

Hesselink M.W., Are we human beings or mere consumers, „European Voice” 18.10. 2006 r., http://www.politico.eu/article/are-we-human-beings-or-mere-co nsumers / (14.10.2015).

Hesselink M.W., CFR and Social Justice, "Centre for the Study of European Contract Law Working Paper Series" 2008, nr 8.

Hesselink M.W., Democratic contract law, "European Review of Contract Law" 2015, R. XI, z. 2.

Hesselink M.W., Europejskie prawo umów: kwestia ochrony konsumenta, obywatelstwa czy sprawiedliwości, „Nowa Europa” 2008, nr 11 (7).

Hesselink M.W., Polityczne aspekty europejskiego koeksu cywilnego, „Kwartalnik Prawa Prywatnego" 2006, R. XV, z. 2.

Hesselink M.W., The New European Legal Culture, Deventer 2001.

Integration Through Law Revisited: The Making of the European Polity, red. D. Augenstein, Ashgate, 2011.

Jedlecka W., Legitymizacja prawa Unii Europejskiej. Legitymizacja demokratyczna czy cywilizacyjna?, Łódź 2014.

Kańska K., Ochrona ekonomicznych interesów konsumentów w prawie Unii Europejskiej na przykładzie dyrektywy 93/13/EWG, [w:] Szkice z prawa Unii Europejskiej, red. E. Piontek, A. Zawidzka, t. II, Kraków 2013.

Kańska K., Pojęcie konsumenta w Kodeksie cywilnym na tle tendencji europejskich, „Kwartalnik Prawa Prywatnego" 2004, nr 1.

Kenig-Witkowska M.M., [w:] Prawo instytucjonalne Unii Europejskiej, red. M.M. Kenig-Witkowska, wyd. 6, Warszawa 2015.

Kövecses Z., Metaphor: A Practical Introduction, Oxford 2010.

Kühn Z., The Judiciary in Central and Eastern Europe: Mechanical Jurisprudence in Transformation?, The Hague 2011.

Kunkiel-Kryńska A., Metody harmonizacji prawa konsumenckiego w Unii Europejskiej i ich wptyw na procesy implementacyjne, Warszawa 2013.

Lacoff G., Johnson M., Metaphors We Live By, Chicago 2003.

Larsson S., Metaphors and Norms: Understanding Copyright in a Digital Society, Lund 2011.

Loos M.B.M., The Influence of European Consumer Law on General Contract Law and the Need for Spontaneous Harmonization, "European Review of Private Law” 2007, R. XV, z. 4.

Lubińska K., Traktat Lizboński a współpraca sądowa w sprawach cywilnych, „Państwo i Prawo" 2008, nr 10.

Łętowska E., Europejskie prawo umów konsumenckich, Warszawa 2002. 
Mańko R., "War of Courts" as a Clash of Legal Cultures: Rethinking the Conflict between the Polish Constitutional Tribunal and the Supreme Court Over 'Interpretive Judgments', [w:] Law, Politics, and the Constitution: New Perspectives from Legal and Political Theory, red. M. Hein i in., Frankfurt am Main 2014.

Mańko R., Contract Law and the Digital Single Market: Towards a new EU online consumer sales law?, studium Biura Analiz Parlamentu Europejskiego sygn. PE 568.322, Brussels 2015 (dostępne: http://ssrn.com/abstract=2660770).

Mańko R., Culture of Private Law in Central Europe After Enlargment: A Polish Perspective, "European Law Journal" 2005, nr 11, z. 5.

Mańko R., European Private Law - In Pursuit of Unity, „Przegląd Prawniczy UW” 2003, R. II, z. 1-2.

Mańko R., Europeanisation of civil procedure: Towards common minimum standards?, studium Biura Analiz Parlamentu Europejskiego, sygn. PE 559.499, Brussels 2015 (http://ssrn.com/abstract=2617949).

Mańko R., Europejski kodekscywilny - stan prac nad projektem i perspektywy dalszego rozwoju, „Studia Iuridica” 2004, t. XLIII (http://ssrn.com/abstract=2069256).

Mańko R., Instytucje UE wobec idei europejskiego kodeksu prawa prywatnego, „Przegląd Prawa Europejskiego" 2004, nr 2 (http://ssrn.com/abstract=2193035).

Mańko R., Kompetencje Unii Europejskiej w dziedzinie prawa prywatnego w ujęciu systemowym, „Kwartalnik Prawa Prywatnego” 2016, R. XXV, z. 1.

Mańko R., Pojęcie interpelacji ideologicznej a krytyczny dyskurs o prawie, „Archiwum Filozofii Prawa i Filozofii Społecznej" 2004, nr 1.

Mańko R., Prawo prywatne w Unii Europejskiej. Perspektywy na przyszłość, Warszawa 2004.

Mańko R., Relikty w kulturze prawnej. Uwagi metodologiczne na tle pozostałości epoki socjalizmu realnego w polskim prawie prywatnym, „Przegląd Prawa i Administracji" 2015, t. 102.

Mańko R., Survival of the Socialist Legal Tradition? A Polish Perspective, "Comparative Law Review" 2013, R. IV, z. 2.

Mańko R., The Impact of EU Membership on Private Law Adjudication in Poland: A Case Study of the Polish Supreme Court's Case Law on Unfair Terms in Consumer Contracts, [w:] Central European Judges Under the European Influence: The Transformative Power of the EU Revisited, red. M. Bobek, Oxford 2015, s. $77-80$.

Mańko R., The Unification of Private Law in Europe from the Perspective of Polish Legal Culture, "Yearbook of Polish European Studies" 2007-2008, nr 11.

Marcisz P., Koncepcja tworzenia prawa przez Trybunał Sprawiedliwości Unii Europejskiej, Warszawa 2015.

Mattei U., Nicola F.G., A "social dimension” in European private law? The call for setting a progressive agenda, „New England LR” 2006, R. XLI, z. 1. 
McGowan L., Theorising European Integration: revisiting neofunctionalism and testing its suitability for explaining the development of EC competition policy?, „European Integration online Papers" 2007, R. XI, z. 3, http://eiop.or.at/eiop/pdf/ 2007-003.pdf.

Micklitz H.W., The EU as a Federal Order of Competences and the Private Law, [w:] The Question of Competence in the European Union, red. L. Azoulai, Oxford 2014.

Mouffe C., Polityczność, Warszawa 2008.

Principles, Definitions and Model Rules of European Private Law. Draft Common Frame of Reference (DCFR). Outline Edition, red. C. von Bar, E. Clive, H. Schulte-Nölke, Munich 2009, http://ec.europa.eu/justice/policies/civil/docs/ dcfr_outline_edition_en.pdf.

Semmelmann C., The Public-Private Divide in European Union Law or an Overkill of Functionalism, "Maastricht Faculty of Law Working Paper" 2012, nr 12, http://ssrn.com/abstract=2056311.

Semmelmann C., Theoretical reflections on the public-private distinction and their traces in European Union law, “Oñati Socio-Legal Series” 2012, R. II, z. 4 http://ssrn.com/abstract=2016077.

Sitek B., Od antropocentryzmu prawniczego do ekonomizacji prawa, [w:] Człowiek pomiędzy prawem a ekonomia w procesie integracji europejskiej, red. G. Dammacco, B. Sitek, O. Cabaj, Olsztyn-Bari 2008.

Sitek B., Prawo jako wartość. Rozważania o autonomii i ponadczasowości prawa w świetle zjawiska ponowoczesności, [w:] Człowiek - Prawo - Państwo. Księga jubileuszowa prof. Stanisława Leszka Stadniczenko, red. J. Jeżewski, A. Pawlak, Warszawa 2017.

Sitek B., Unifikować czy synchronizować prawo w Europie? Studium przypadku od prawa rzymskiego do prawa europejskiego, "Journal of Modern Science" 2016, t. II.

Sprawiedliwość społeczna w europejskim prawie umów: manifest, („European Law Journal" 2004), przekład polski w: „Nowa Europa” 2008, nr 11(7).

Stambulski M., Paździora M., Co może dać nauce prawa polityczność? Przyczynek do przyszłych badań, „Archiwum Filozofii Prawa i Filozofii Społecznej” 2014, nr 1.

Stępień M., Systemowość prawa Unii Europejskiej, Poznań 2008.

Wudarski A., Wspólny System Odniesienia - na drodze do europejskiego kodeksu cywilnego?, [w:] Współczesne problemy w administracji publicznej. Wybrane zagadnienia, red. P. Chmielnicki i in., Częstochowa 2008.

Zając-Frąs M., Teorie i modele integracji europejskiej, "Zeszyty Naukowe Uniwersytetu Ekonomicznego w Krakowie" 2011, nr 852.

Ziemblicki B., Zbliżanie ustawodawstw państw członkowskich Unii Europejskiej w zakresie prawa prywatnego, „Folia Iuridica Wratislaviensis” 2012, R. I, z. 1.

Zimmermann R., Prawo rzymskie a harmonizacja prawa prywatnego w Europie, „Nowa Europa" 2008, t. 11.

Zirk-Sadowski M., Prawo a uczestniczenie w kulturze, Łódź 1998.

Zweigert K., Kötz H., Introduction to Comparative Law, wyd. 3, Oxford 1998. 